in the tenth year of his reign. Ivory, glass and faience objects include a beautiful small ivory mask. The art of this and other carved objects, including a carved hand, three-quarter life size, suggest an artistic relation of some kind with Tell Amarna. Some ivories, much calcined by fire, including a remarkable perfume vase fashioned from an ivory tusk, are delicate examples of the engraver's art. A plaque of Rameses II points to the destruction of the temple having taken place not later than 1262 B.c., but until the levels below the temple have been examined, it is not possible to suggest the date of its foundation.

\section{Fuel Research in Great Britain}

IN the course of a normal year, about six hundred visitors are received at the Fuel Research Station, Greenwich, but the Fuel Research Board has come to the conclusion that, in addition, a general visitation would be a valuable means of bringing the Station's work before industry and the public. The first visitation was held on June 25, when about three hundred guests were received by Sir Harold Hartley (chairman of the Fuel Research Board), Dr. F. S. Sinnatt (Director of Fuel Research) and Sir Frank Smith (secretary of the Department of Scientific and Industrial Research). The visitors were given an opportunity of seeing practically all the modern methods in the study and treatment of coal. Demonstrations of coal-washing, by wet and dry systems, attracted a large number of visitors. A rotary coal dryer and mill for pulverising, together with such burners as the 'Grid' and 'Vortex' for the powdered fuel, were shown in operation. Coal-oil suspensions showed one line along which research is being conducted with the view of making coal a more flexible fuel. Specimens of the liquid products of low-temperature carbonisation were shown. But perhaps the focus of interest for most visitors was in the hydrogenation building, where compressors for delivering hydrogen at a pressure of 200 atmospheres, and the converters in which the reaction takes place at that pressure and a temperature of $480^{\circ} \mathrm{C}$., were demonstrated in action.

\section{Foot-and-Mouth Disease}

Some interesting information was given by the Minister of Agriculture in the House of Commons on June 25, when Sir Arnold Wilson asked two questions on the subject of foot-and-mouth disease at the request of the Parliamentary Science Committee. Sir Arnold asked what progress has been made by the Foot-and-Mouth Disease Research Committee during the last two years; and what, broadly speaking, the results of its investigations have been, more particularly in the direction of preventive treatment by inoculation. Mr. Elliot promised a memorandum on the subject in reply and stated that the Fifth Progress Report of the Committee is in course of preparation, and is expected to be available in the autumn. Sir Arnold also asked whether the Committee has considered the possible connexion between the quality of the food of cattle and the incidence of this disease; and whether the Committee is dealing with the question of the prevention of foot-and-mouth disease by a combination of high-quality food and improved hygiene. $\mathrm{Mr}$. Elliot in his reply stated that the Committee has advised that there is "no evidence to show that diet or hygiene, or a combination of both, have any influence on the spread of foot-and-mouth disease. Clinical observations and experimental work carried out by the Committee have in fact shown that animals in very good condition may contract the disease in a more severe form than animals in poor condition". Referring to the possible spread of footand-mouth disease by imported straw, in answer to a question by Col. Acland-Troyte, Mr. Elliot stated that the importation into Great Britain from countries where foot-and-mouth disease exists of hay and straw for use as fodder or litter for animals is prohibited, and imported straw used for packing merchandise has to be destroyed after use; there does not appear to be justification for further prohibition of the importation of this material.

\section{Educational Sound Films}

UNDER the auspices of the British Film Institute, 4, Great Russell Street, London, W.C.1, a private demonstration of educational sound films was presented at the Academy Cinema, London, on June 21, before teachers and educationists. As Mr. H. Ramsbotham, M.P., Parliamentary Secretary to the Board of Education, pointed out in his introductory address, such films must not be accepted without reservation, for they should always be looked upon as being supplementary to the teacher himself. The production of the films shown was a piece of pioneer work and experimental in character, and the venture augurs well for the future of the cinematograph in education, especially if the producers receive the constructive criticism from teachers for which they ask. There is little doubt that, provided it is not abused, the sound film will prove an important asset to the teacher of the future. The seven films presented on this occasion clearly showed not only the expert film producers we have at our command, but also where the film will be a useful aid and where it will prove an unwelcome intruder.

THE films of the life-history of the thistle, the growth and irritability of roots, and the physiology of breathing were examples of good educational films-useful tools in the hands of a responsible teacher. They showed the value of the cinematograph film in photomicrography and in demonstrating those types of motion too slow to be watched normally. The film of wheatlands in East Anglia, too, was a good lesson in economic geography and rural science, and demonstrated the possibilities of the film in transporting a class to the actual scene of action, which otherwise has to be done, rather inefficiently, by laborious verbal teaching and much reading. Such films indicate the lines along which it is to be hoped the cinematograph in education will develop. On the other hand, certain films shown depicted the dangers inherent in the cinematograph 
as a teaching factor. That on kitchencraft, for example, merely illustrated the processes involved in making a pork pie. Most domestic science teachers, we think, would prefer their pupils to learn such a lesson by doing it themselves. But this is only the experimental stage, and though there is much to learn, a great deal of good work has already been done. To add to their value, the films are produced under authoritative direction. The films shown were made by Gaumont-British Instructional, Ltd., 12 D'Arblay Street, Oxford Street, W.1, who are to be congratulated on the excellent production, beautiful photography and useful running commentary. The whole performance will be presented later in provincial towns.

\section{Repton School Science Society}

ThE Repton School Science Society held its triennial conversazione in the Science School on June 22-23, when some fifty demonstrations and exhibits in biology, chemistry, and physics were shown by members of the Society. In the biology section a demonstration of the circulation of the blood in the tail of a tadpole was shown, both the pulse and the corpuscles being clearly visible. The laboratory aquarium and numerous specimens collected by the members were also shown. Two points of interest in the chemistry section were a demonstration of the spinning, bleaching, and 'souring' of rayon by a home-made model, and a set of experiments on testing the hardness of water and the various methods of water softening. Perhaps the most conspicuous feature of the physics section was a lecture on the electric spark, which included an elementary account of the mechanism of the spark, illustrated by various experiments on ionisation. The conversazione was well attended, and the visitors were impressed by the able manner in which the lectures and demonstrations were given.

\section{Architects' Unemployment Committee's Exhibition}

A N.ATIONAL crisis must naturally affect immediately those fields of activity most removed from the provision of essential necessities, and at the close of 1931 architects felt very severely the curtailment of their work due to restrictions required by economy. The Royal Institute of British Architects, in this emergency, set up a relief scheme in the form of payment for useful work of a public character made possible by subscriptions to a relief fund started by this and other kindred institutions. A sum of nearly $£ 12,000$ was collected, the whole of which has been expended in salaries and incidental costs in making surveys which should be of considerable value. The results are displayed on maps and models now on exhibition at 7, Bedford Square, London. Here on the 25-in. ordnance map may be seen indicated by colours the disposition of public, commercial and industrial buildings, business premises, and private and municipal housing over the whole of the London district and much of Kent. A 6-in. map shows London factories, shops, clubs, banks, and public buildings. A survey of the heights of London buildings has also been made and recorded. An interesting model of the London area is displayed showing the growth of London by centuries from Roman times to the present day. The information which can be grasped from the exhibition at a glance is most striking, and the maps should be of great value to Government and municipal departments. The display suffers from inadequate space, and though ingeniously arranged on curved surfaces, a comparison of the Hampton Court area on the walls with Greenford on the ceiling at some distance is not easy. The exhibition was opened by Lord Snell on June 22.

\section{Leadership in Industry}

IN the Mather Lecture of the Textile Institute delivered on May 25, Mr. A. P. Young (J. Text. Inst., May) gives a stimulating discussion of the functions and opportunities of industrial leadership. Reviewing the origin of the scientific era and the imperative necessity for adequate leadership in this age of power production, he sees in it the opportunity for many of the inspired qualities and the spirit of adventure which have animated previous pioneers of creative thought. Such leadership should be capable of harnessing to the task of industrial evolution, world co-operation and reconstruction the increasing productivity of the human unit, the accelerated rate at which raw materials are brought into service, the development of the electrical power era, the diminution of the time lag between discovery and industrial application, the linking of production and distribution. This must be done on a basis of planned co-operation, and leadership will function largely through its ability to stimulate the essential spirit of team work.

Mr. Young discusses the qualities required in the industrial leader of this calibre, among which he lists this ability to foster team work, creative imagination, intellectual sincerity and moral courage, power to co-operate with others, knowledge of administrative principles, capacity for delegating authority and scientific and technical knowledge. He emphasises the importance of a science as well as an art of management, and asserts that education for management is one of our greatest national needs, the need extending to the training of foremen and supervisors as well as managers and leaders carrying high responsibilities. Mr. Young discusses in some detail the problems of planning and leadership in the textile industry, laying stress on the service motive in industry. He sees a great future for the textile industry when planned and led along such lines, and concludes with a plea for co-ordination of the activity of the five research associations which now exist and for a five-fold expansion of the industry's expenditure on research within the next five years.

\section{A Photographic Centenary}

ON June 23, a gathering took place at Laycock Abbey, Wiltshire, to do honour to Henry Fox Talbot, who in 1834 in that house first succeeded in producing photographic impressions on paper. Fox Talbot, who was born in 1800 and died in 1877 , graduated at Cambridge in 1821, and became known 